\title{
Influence of annealing on microstructure and optical properties of hot wall deposited $\mathrm{Pb}_{\mathrm{x}} \mathrm{Sn}_{(1-\mathrm{x})} \mathrm{S}$ thin films
}

\author{
S.A. Bashkirov ${ }^{\text {a,*, V.F. Gremenok }}{ }^{a}$, V.A. Ivanov ${ }^{\text {a }}$, K. Bente ${ }^{\text {b }}$, P.P. Gladyshev ${ }^{c}$, T.Yu. Zelenyak $^{\mathrm{c}}$, \\ A.M. Saad ${ }^{\mathrm{d}}$, M.S. Tivanov ${ }^{\mathrm{e}}$ \\ a State Scientific and Production Association "Scientific-Practical Materials Research Centre of the National Academy of Sciences of Belarus", P. Brovka str. 19, 220072 Minsk, Belarus \\ b Institut für Mineralogie, Kristallographie und Materialwissenschaft, Universitat Leipzig, Scharnhorststr. 20, 04275 Leipzig, Germany \\ c Dubna International University for Nature, Society and Man, Universitetskaya str. 19, 141980 Dubna, Moscow Oblast, Russia \\ d Al-Balqa Applied University, PO Box 4545, Amman 11953, Jordan \\ e Belarusian State University, Nezavisimosti av. 4, 220030 Minsk, Belarus
}

\section{A R T I C L E I N F O}

Article history:

Received 28 December 2015

Received in revised form 20 September 2016

Accepted 3 October 2016

Available online 04 October 2016

\section{Keywords:}

Lead-tin sulfide

Thin films

Microstructure

Optical properties

Electrical properties

\begin{abstract}
A B S T R A C T
$\mathrm{Pb}_{\mathrm{x}} \mathrm{Sn}_{(1-\mathrm{x})} \mathrm{S}(0.05<x<0.20)$ thin films with the thickness of $2 \mu \mathrm{m}$ were deposited on glass substrates using hot wall vacuum deposition method at the vacuum pressure of $5 \times 10^{-4} \mathrm{~Pa}$, wall temperature of $600^{\circ} \mathrm{C}$, substrate temperature of $300^{\circ} \mathrm{C}$ and subsequently annealed at $450{ }^{\circ} \mathrm{C}$ in vacuum at $5 \times 10^{-4} \mathrm{~Pa}$. The microstructure and optical properties of the as-deposited and annealed films were examined in relation to the film composition. The explanations of lattice parameter deviations from the bulk crystals for both as-deposited and annealed $\mathrm{Pb}_{\mathrm{x}} \mathrm{Sn}_{(1-\mathrm{x})} \mathrm{S}$ thin films are discussed. The $\mathrm{Pb}_{\mathrm{x}} \mathrm{Sn}_{(1-\mathrm{x})} \mathrm{S}$ thin films exhibit a preferred orientation around the [111] direction. The annealing decreases the film microstrain values and increases the grain size and the degree of preferred orientation. Thermal probe measurements showed the sulfur-deficient films to be $p$-type and the sulfur-rich films to be $n$-type. The $\mathrm{Pb}_{\mathrm{x}} \mathrm{Sn}_{(1-\mathrm{x})} \mathrm{S}$ films exhibit direct allowed transitions with energy band gap $E_{g(d)}$ increasing with the increase of $\mathrm{Pb}$ mole fraction. The $E_{g(d)}$ values for as-deposited films range from 0.95 to $0.98 \mathrm{eV}$ and for annealed films they variy from 0.90 to $0.94 \mathrm{eV}$.
\end{abstract}

(c) 2016 Elsevier B.V. All rights reserved.

\section{Introduction}

The $\mathrm{A}^{\mathrm{IV}} \mathrm{B}^{\mathrm{VI}}$ chalcogenide semiconductors rise interest for optoelectronics and photovoltaics due to their high optical absorption coefficient in the visible and near infra-red (IR) range. In recent papers, tin sulfide $\mathrm{SnS}$ is discussed as an alternative light-absorbing material for thin-film solar cells $[4,31,32]$. The $\mathrm{A}^{\mathrm{IV}} \mathrm{B}^{\mathrm{VI}}$ semiconductor lead sulfide $(\mathrm{PbS})$ is efficiently used in industrial IR receivers for a long time.

In the PbS-SnS quasi-binary system the solid solutions of $\mathrm{Pb}_{\mathrm{X}} \mathrm{Sn}_{(1-\mathrm{x})} \mathrm{S}$ are determined for $0<x<0.5$ and for $0.9<x<1[21,38]$. The SnS-rich solutions crystallize at temperatures $<600{ }^{\circ} \mathrm{C}$ in the $\alpha$-SnS (S.G. Pbnm) GeS type. The $\mathrm{PbS}$ rich phases corresponding to the subsolidus region exhibit a cubic phase related to PbS (S.G. Fm-3m, NaCl type). Additionally, the mineral teallite with a fixed composition of $x=0.5\left(\mathrm{~Pb}_{0.5} \mathrm{Sn}_{0.5} \mathrm{~S}\right)$ displays an orthorhombic structure with the lattice parameters $a=4.269 \AA$, $b=$ $11.430 \AA, c=4.086 \AA[18,21]$. This corresponds to the $\alpha$-SnS structure with the lattice parameters $a=4.330 \AA, b=11.195 \AA$, $c=3.978 \AA$ [21].

\footnotetext{
* Corresponding author.

E-mail address: sp-box@yandex.ru (S.A. Bashkirov).
}

Different methods for SnS thin film deposition have been developed including co-evaporation [8], sulfurization [26], electron beam evaporation [35], spray-pyrolysis [7], thermal vacuum evaporation [10], hot wall deposition [2-6,32,41]. The optical investigations showed that those SnS thin films energy band gap values change in a wide range from 1.07 to $1.7 \mathrm{eV}$, strongly depending on the microstructure including crystal structure defects, grain size, side phases, etc. [2,3,5-8,10,26,35, 41]. Theoretical energy band structure calculations lead to the different values depending on the calculation method. Thus, in [14] the energy band gap is calculated for direct transitions to be $1.8 \mathrm{eV}$, but in [25] it is $1.16 \mathrm{eV}$.

Although $\mathrm{SnS}$ is well-studied, $\mathrm{Pb}_{0.5} \mathrm{Sn}_{0.5} \mathrm{~S}$ and $\mathrm{Pb}_{\mathrm{x}} \mathrm{Sn}_{(1-\mathrm{x})} \mathrm{S}$ series are not investigated in detail. The theoretically calculated energy band gap values for $\mathrm{Pb}_{0.5} \mathrm{Sn}_{0.5} \mathrm{~S}$ are $0.64 \mathrm{eV}$ [33] and $1.1 \mathrm{eV}$ [34]. Experimental measurements of $\mathrm{Pb}_{0.5} \mathrm{Sn}_{0.5} \mathrm{~S}$ optical energy band gap reveal $E_{g(d)}=$ $1.65 \mathrm{eV}$ for direct transitions and $E_{g(i)}=0.96 \mathrm{eV}$ for indirect transitions [37]. For $\mathrm{Pb}_{\mathrm{x}} \mathrm{Sn}_{(1-\mathrm{x})} \mathrm{S}$, with $x$ increasing from 0.25 to $0.45, E_{g(d)}$ increased from 1.25 to $1.31 \mathrm{eV}$ and $E_{g(i)}$ decreased from 1.06 to 0.96 [22]. However, the authors of [22] pointed out that there might be errors in the band gap determination due to the extremely low linear parts of the absorption spectra. To our knowledge, there are no reports on the 
optical behavior of $\mathrm{Pb}_{\mathrm{x}} \mathrm{Sn}_{(1-\mathrm{x})} \mathrm{S}$ with $x<0.20$. Therefore, basic optical characteristics of $\mathrm{Pb}_{\mathrm{x}} \mathrm{Sn}_{(1-\mathrm{x})} \mathrm{S}$ over the whole mole fraction range have to be determined.

Applicability of such materials for photosensitive device structures (including $\operatorname{In} / \mathrm{Pb}_{\mathrm{x}} \mathrm{Sn}_{(1-\mathrm{x})} \mathrm{S}$ Schottky barriers) based on $\mathrm{Pb}_{\mathrm{x}} \mathrm{Sn}_{(1-\mathrm{x})} \mathrm{S}$ thin films was reported in [15]. A notable feature of $\mathrm{Pb}_{\mathrm{x}} \mathrm{Sn}_{(1-\mathrm{x})} \mathrm{S}$ is that its most important physical and morphology characteristics can be controlled by varying the chemical composition. Additionally, nano-structured thin films with non-trivial morphology (nano-whiskers etc.) $[20,39]$ may lead to a wide field of the $\mathrm{Pb}_{\mathrm{x}} \mathrm{Sn}_{(1-\mathrm{x})} \mathrm{S}$ thin films practical applications.

Recently we reported an effective control of the SnS thin film microstructure by thermal [6] and plasma [41] procedures. In this paper we present the study of thermal treatment influence onto the microstructure and optical properties of $\mathrm{Pb}_{\mathrm{x}} \mathrm{Sn}_{(1}{ }_{-\mathrm{x})} \mathrm{S}$ thin films with $0.05<x<0.20$ obtained by a hot wall vacuum deposition method (HWVD).

\section{Experimental details}

Corning 7059 glass plates used as substrates were chemically cleaned with $96 \%$ ethanol, rinsed with distilled water and dried by compressed air before the sulfide deposition. $\mathrm{The}^{\mathrm{Pb}} \mathrm{Sn}_{(1-\mathrm{x})} \mathrm{S}$ thin films were deposited on the substrates using HWVD method [23] at the vacuum pressure of $5 \times 10^{-4} \mathrm{~Pa}$, wall temperature of $600^{\circ} \mathrm{C}$ and substrate temperature of $300^{\circ} \mathrm{C}$. The film growth rate under these conditions was around $100 \mathrm{~nm} / \mathrm{min}$. In order to obtain the films with $2 \mu \mathrm{m}$ thickness the deposition time was restricted to 20 min. Powdered polycrystalline $\mathrm{Pb}_{\mathrm{x}} \mathrm{Sn}_{(1-\mathrm{x})} \mathrm{S}$ obtained by fusing 99.999\% pure lead, tin and sulfur in the desired ratio were used as precursors. The distance between the source and the substrate was $12 \mathrm{~cm}$. The films were annealed for $1 \mathrm{~h}$ at $450{ }^{\circ} \mathrm{C}$ in vacuum at $5 \times 10^{-4} \mathrm{~Pa}$. These conditions are also applied for the thermal treatment of SnS thin films [6].

The crystal structure and phase composition of the $\mathrm{Pb}_{\mathrm{x}} \mathrm{Sn}_{(1-\mathrm{x})} \mathrm{S}$ thin films were studied by X-ray diffraction (XRD) in the BraggBrentano geometry using a Siemens D-5000 diffractometer with $\mathrm{CuK}_{\alpha}(\lambda=1.5418 \AA)$ radiation. Silicon wafer was used as a reference. The observed phases were determined by comparing the $d$-spacings with the Joint Committee on Powder Diffraction Standard (JCPDS) and Open Crystallography Database data files. Rietveld analysis [29], implemented in the "Material Analysis Using Diffraction (MAUD)" software package [24] was used for the lattice and other structural parameters refinement. March-Dollase model [13,27,42] was used to have regard to the preferred orientation in the Rietveld analysis. Chemical composition of the films was checked by energy dispersive X-ray microanalysis (EDX) using AN 10000 spectrometer. The voltage used for accelerating the electron beam in EDX measurements was $15 \mathrm{kV}$. Surface morphology of the deposited material was investigated by scanning electron microscopy (SEM) using JEOL 6400 and LEO1455VP microscopes. Optical characteristics of the films were derived from the transmission spectra measured in the range of 400-2500 nm using Specord PC 210 UV-VIS spectrometer with a resolution of $1 \mathrm{~nm}$. The temperature coefficient of thermoelectric power (Seebeck coefficient) and the conduction type were determined by the thermoprobe method. The electrical resistivity was determined by the van der Pauw method at room temperature $(T=300 \mathrm{~K})$.

\section{Results and discussion}

A typical EDX spectrum of the $\mathrm{Pb}_{\mathrm{x}} \mathrm{Sn}_{(1-\mathrm{x})} \mathrm{S}$ thin film is presented in Fig.1. The obtained films do not contain any extrinsic elements that could be found by EDX. Typical elemental compositions of the films are presented in Table 1.

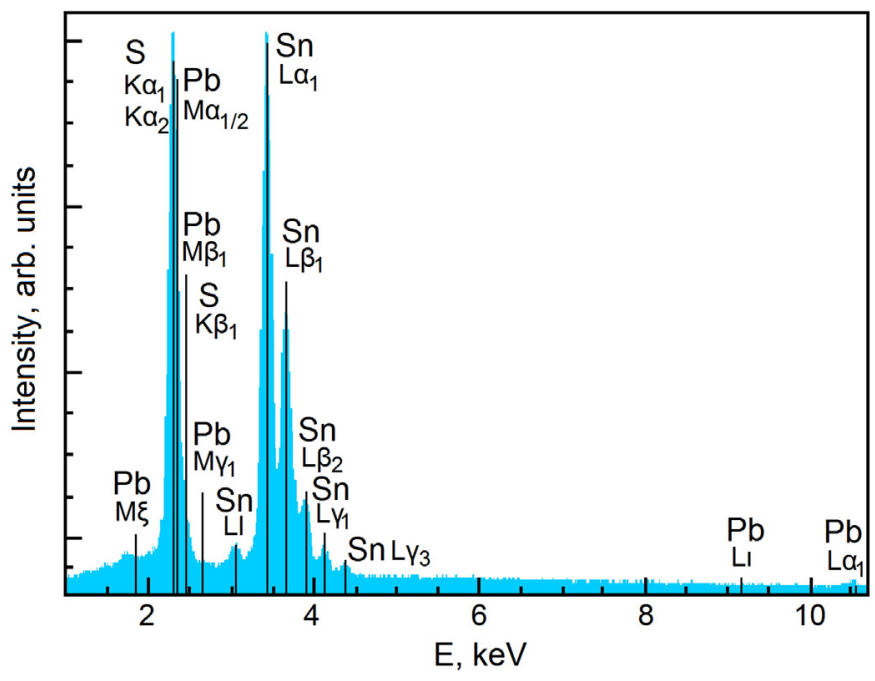

Fig. 1. Typical EDX spectrum of $\mathrm{Pb}_{\mathrm{x}} \mathrm{Sn}_{(1-\mathrm{x})} \mathrm{S}$ thin film.

The $\mathrm{Pb}$ mole fraction $x$ and stoichiometry deviation factor $\delta$ in $\mathrm{Pb}_{\mathrm{x}} \mathrm{Sn}_{(1-\mathrm{x})} \mathrm{S}_{(1+\delta)}$ were calculated from atomic ratios using the following equations:

$$
\begin{aligned}
& x=\frac{\omega(\mathrm{Pb})}{\omega(\mathrm{Pb})+\omega(\mathrm{Sn})} \\
& \delta=\frac{\omega(\mathrm{S})}{\omega(\mathrm{Pb})+\omega(\mathrm{Sn})}-1
\end{aligned}
$$

where $\omega(\mathrm{Pb}), \omega(\mathrm{Sn}), \omega(\mathrm{S})$ are atomic percents of $\mathrm{Pb}, \mathrm{Sn}$ and $\mathrm{S}$, respectively.

The calculations showed the obtained films to exhibit $x$ value of $0.05<x<0.20$, which is in agreement with the starting composition of the evaporated polycrystals. The $\delta$ values vary from minus 0.19 to plus 0.18 . Those deviations may be caused by the high vapor pressure of sulfur [40] at the substrate temperature used in this work. The EDX analysis of the as-deposited and annealed films showed that annealing under conditions mentioned above does not lead to any changes in the film composition for both sulfur-rich and sulfur-poor films.

The XRD pattern of $\mathrm{Pb}_{\mathrm{x}} \mathrm{Sn}_{(1-\mathrm{x})} \mathrm{S}$ film (Fig. 2) shows the presence of orthorhombic structure of $\alpha$-SnS (S.G. Pbnm, GeS type). XRD patterns of sulfur-poor films $(\delta<0)$ contain only $\alpha$-SnS reflections, while patterns of sulfur-rich films $(\delta>0)$ in some cases contain additional reflections of phases with hexagonal $\mathrm{SnS}_{2}$ (S.G. $P 6_{3} m c$ ) and orthorhombic $\mathrm{Sn}_{2} \mathrm{~S}_{3}$ (S.G. Pnam). Besides $\mathrm{SnS}, \mathrm{Sn}_{2} \mathrm{~S}_{3}, \mathrm{SnS}_{2}, \mathrm{PbS}$ and $\mathrm{PbSnS}_{2}$, such phase as $\mathrm{PbSnS}_{3}$ with $\mathrm{Sn}_{2} \mathrm{~S}_{3}$ orthorhombic structure can be formed in the ternary $\mathrm{Pb}-\mathrm{Sn}-\mathrm{S}$ system [1]. The PbSnS 3 forms from $\mathrm{PbS}$ and $\mathrm{SnS}_{2}$ at $600{ }^{\circ} \mathrm{C}$ [1], that corresponds to the wall temperature applied in the HWVD method in this work. Given that, the observed phase with $\mathrm{Sn}_{2} \mathrm{~S}_{3}$ structure may be assigned to $\mathrm{PbSnS}_{3}$.

Structural and microstructural properties of $\mathrm{Pb}_{\mathrm{x}} \mathrm{Sn}_{(1-\mathrm{x})} \mathrm{S}$ thin films including lattice parameters, microstrain and grain size obtained form room temperature XRD measurements for different chemical compositions are presented in Table 1. The dependence of $\mathrm{Pb}_{\mathrm{x}} \mathrm{Sn}_{(1-\mathrm{x})} \mathrm{S}$ lattice

Table 1

Composition of the $\mathrm{Pb}_{\mathrm{x}} \mathrm{Sn}_{(1-\mathrm{x})} \mathrm{S}$ thin films.

\begin{tabular}{llllll}
\hline \multicolumn{6}{l}{ Elemental composition, at.\% } \\
\hline $\mathrm{Pb}$ & $\mathrm{Sn}$ & $\mathrm{S}$ & $x$, arb. units & $\delta$, arb. units & Molar composition \\
\hline 2.80 & 52.35 & 44.85 & 0.05 & -0.19 & $\mathrm{~Pb}_{0.05} \mathrm{Sn}_{0.95} \mathrm{~S}_{0.81}$ \\
6.90 & 39.00 & 54.10 & 0.15 & 0.18 & $\mathrm{~Pb}_{0.15} \mathrm{Sn}_{0.85} \mathrm{~S}_{1.18}$ \\
10.20 & 41.80 & 48.00 & 0.20 & -0.08 & $\mathrm{~Pb}_{0.20} \mathrm{Sn}_{0.80} \mathrm{~S}_{0.92}$ \\
\hline
\end{tabular}




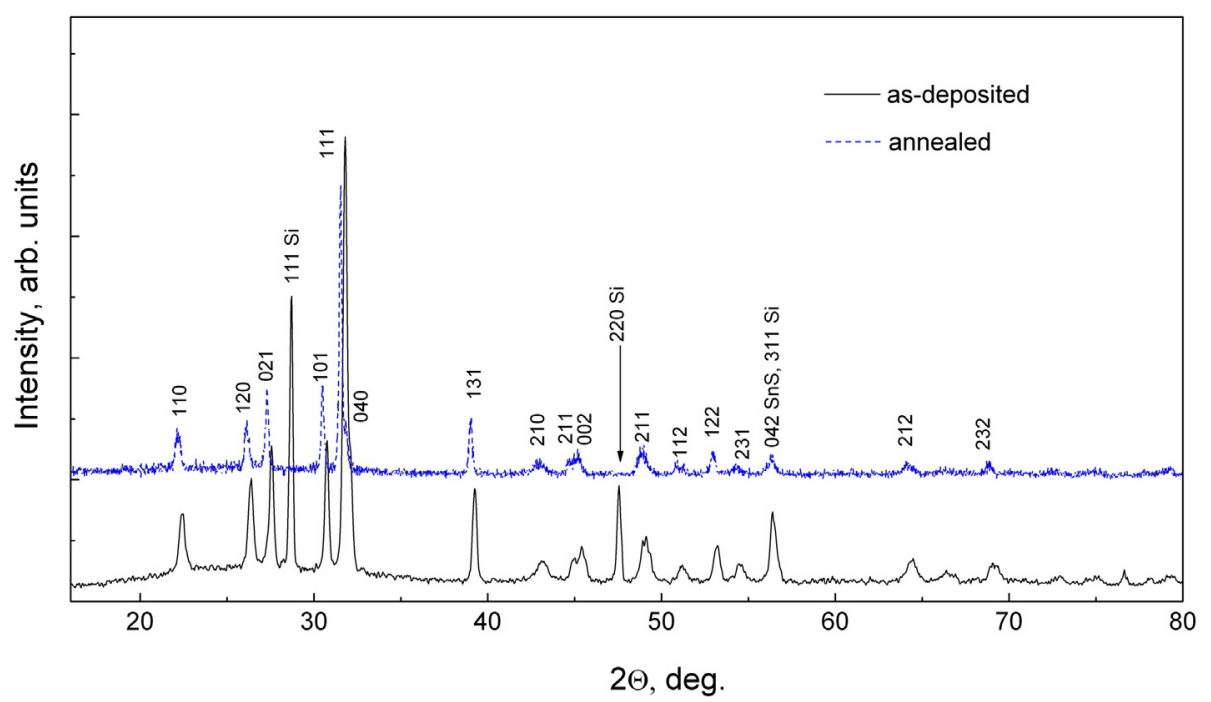

Fig. 2. Typical XRD pattern of $\mathrm{Pb}_{\mathrm{X}} \mathrm{Sn}_{(1-\mathrm{x})} \mathrm{S}$ thin film.

parameters on $\mathrm{Pb}$ mole fraction $x$ in the range from 0 to 0.5 is described by the following equations [21]:

$$
\begin{aligned}
& a=4.2077+0.1218(1-x), \\
& b=11.6657-0.4706(1-x), \\
& c=4.19360-0.2155(1-x),
\end{aligned}
$$

Comparing to the bulk crystal lattice parameters [21], the $a$ parameter of the $\mathrm{Pb}_{\mathrm{x}} \mathrm{Sn}_{(1-\mathrm{x})} \mathrm{S}$ thin films is significantly lower and the $b$ and $c$ parameters of the thin films are higher than that of the bulk crystals. These lattice deviations from the bulk material are typical for both asdeposited and annealed $\mathrm{Pb}_{\mathrm{X}} \mathrm{Sn}_{(1-\mathrm{x})} \mathrm{S}$ thin films. However, thermal treatment at $450{ }^{\circ} \mathrm{C}$ leads to the decrease of all three lattice parameters, which is in contradistinction to the substrate temperature of $300{ }^{\circ} \mathrm{C}$. This may be due to the removal of microstresses primarily produced during the film growth. The same effect of annealing was observed for the lattice parameters of the SnS thin films [6]. However, it can be noticed that the deviations of $b$ and $c$ lattice parameters from the bulk data decrease after annealing, while the deviation of the $a$ parameter increases (Table 2).

The microstrain $\varepsilon$ and grain size $D$ values were calculated using MAUD software [24] based on models from [9]. The annealing results in the decreased $\varepsilon$ values and increased $D$ as expected, because the increase of grain size relates to a favorable reduction of surface energy due to minimization of specific surface area. However, in [11] the

Table 2

\begin{tabular}{|c|c|c|c|c|c|c|}
\hline \multirow{2}{*}{\multicolumn{2}{|c|}{ Composition and type }} & \multicolumn{3}{|c|}{$\begin{array}{l}\text { Lattice parameters, } \AA \\
(\text { error } \pm 0.002 \AA)\end{array}$} & \multirow[b]{2}{*}{$\varepsilon, \%$} & \multirow[b]{2}{*}{$D, \mathrm{~nm}$} \\
\hline & & $a$ & $b$ & c & & \\
\hline$\alpha$-SnS crystals & & 4.330 & 11.195 & 3.978 & - & - \\
\hline \multirow[t]{3}{*}{$\mathrm{Pb}_{0.05} \mathrm{Sn}_{0.95} \mathrm{~S}_{0.81}$} & As-deposited & 4.293 & 11.251 & 4.017 & $0.17 \pm 0.01$ & $92 \pm 5$ \\
\hline & Annealed & 4.287 & 11.232 & 4.015 & $0.13 \pm 0.01$ & $175 \pm 13$ \\
\hline & Crystals & 4.322 & 11.222 & 3.994 & - & - \\
\hline \multirow[t]{3}{*}{$\mathrm{Pb}_{0.15} \mathrm{Sn}_{0.85} \mathrm{~S}_{1.18}$} & As-deposited & 4.287 & 11.340 & 4.037 & $0.16 \pm 0.01$ & $80 \pm 10$ \\
\hline & Annealed & 4.277 & 11.309 & 4.013 & $0.10 \pm 0.04$ & $100 \pm 10$ \\
\hline & Crystals & 4.311 & 11.266 & 4.010 & - & - \\
\hline \multirow[t]{3}{*}{$\mathrm{Pb}_{0.20} \mathrm{Sn}_{0.80} \mathrm{~S}_{0.92}$} & As-deposited & 4.266 & 11.329 & 3.998 & $0.20 \pm 0.02$ & $391 \pm 13$ \\
\hline & Annealed & 4.260 & 11.315 & 4.000 & $0.15 \pm 0.05$ & $317 \pm 5$ \\
\hline & Crystals & 4.305 & 11.289 & 4.021 & - & - \\
\hline \multicolumn{2}{|c|}{$\mathrm{Pb}_{0.5} \mathrm{Sn}_{0.5} \mathrm{~S}$ crystals } & 4.269 & 11.430 & 4.086 & - & - \\
\hline
\end{tabular}

Structural parameters for $\mathrm{Pb}_{\mathrm{x}} \mathrm{Sn}_{(1-\mathrm{x})} \mathrm{S}$ thin films (in this work) and crystals (taken from [21]) of different compositions. opposite tendency was reported, namely, the grain size decreased after the thermal treatment.

The degree of preferred orientation, varying from $0 \%$ for randomly oriented powder to $100 \%$ for a single crystal, was estimated from the value of the March-Dollase model parameter $r$ by the following equation [42]:

$\eta=100 \%\left[\frac{(1-r)^{3}}{1-r^{3}}\right]^{1 / 2}$

The $\mathrm{Pb}_{\mathrm{x}} \mathrm{Sn}_{(1-\mathrm{x})} \mathrm{S}$ thin films exhibited a preferred orientation with $\eta=41 \%$ in the [111] direction independent on film composition. Close values for the degree of preferred orientation were observed for SnS films [6] deposited by HWVD in conditions similar to those that we used in this study. The thermal treatment does not significantly affect the degree of preferred orientation and leads to its minimal increase in the range of $1-2 \%$, that might be due to the surface energy minimization effect mentioned above.

\subsection{Morphology}

Fig. 3 shows typical SEM images of the $\mathrm{Pb}_{\mathrm{x}} \mathrm{Sn}_{(1-\mathrm{x})} \mathrm{S}$ film surface for the as-deposited and annealed films of different composition. So, the film surface morphology strongly depends on the lead mole fraction $x$. For $\mathrm{Pb}$-poor films, petal-like crystallites with an average size of $10 \mathrm{~nm} \times 200 \mathrm{~nm} \times 900 \mathrm{~nm}$ were observed and the longest extension of each crystallite aligns mainly vertically to the substrate. The same surface morphology was previously observed for SnS films obtained by a number of methods $[3,4,16,17,30,32]$. As the $\mathrm{Pb}$ mole fraction increases, the crystallites form a compact layer. The most compact morphology relates to the films with $\mathrm{Pb}$ mole fraction of $x=0.20$ (Fig. 4e, f). According to these results, the annealing has a minimal impact on $\mathrm{Pb}_{\mathrm{x}} \mathrm{Sn}_{(1-\mathrm{x})} \mathrm{S}$ surface morphology in the range of compositions mentioned above. The morphology of Pb-poor films was minimally affected by annealing. Films with a molar fraction of $x \geq 0.15$ showed that the annealing leads to a rounding of crystallite faces, which can be associated with the melting, diffusion and re-evaporation processes occurring during annealing.

\subsection{Electrical and optical properties}

According to the thermal probe measurements, the sulfur deficient $(\delta=-0.19)$ films are $p$-type and the sulfur rich $(\delta=+0.18)$ films are $n$-type regardless of the annealing and lead concentration. This 

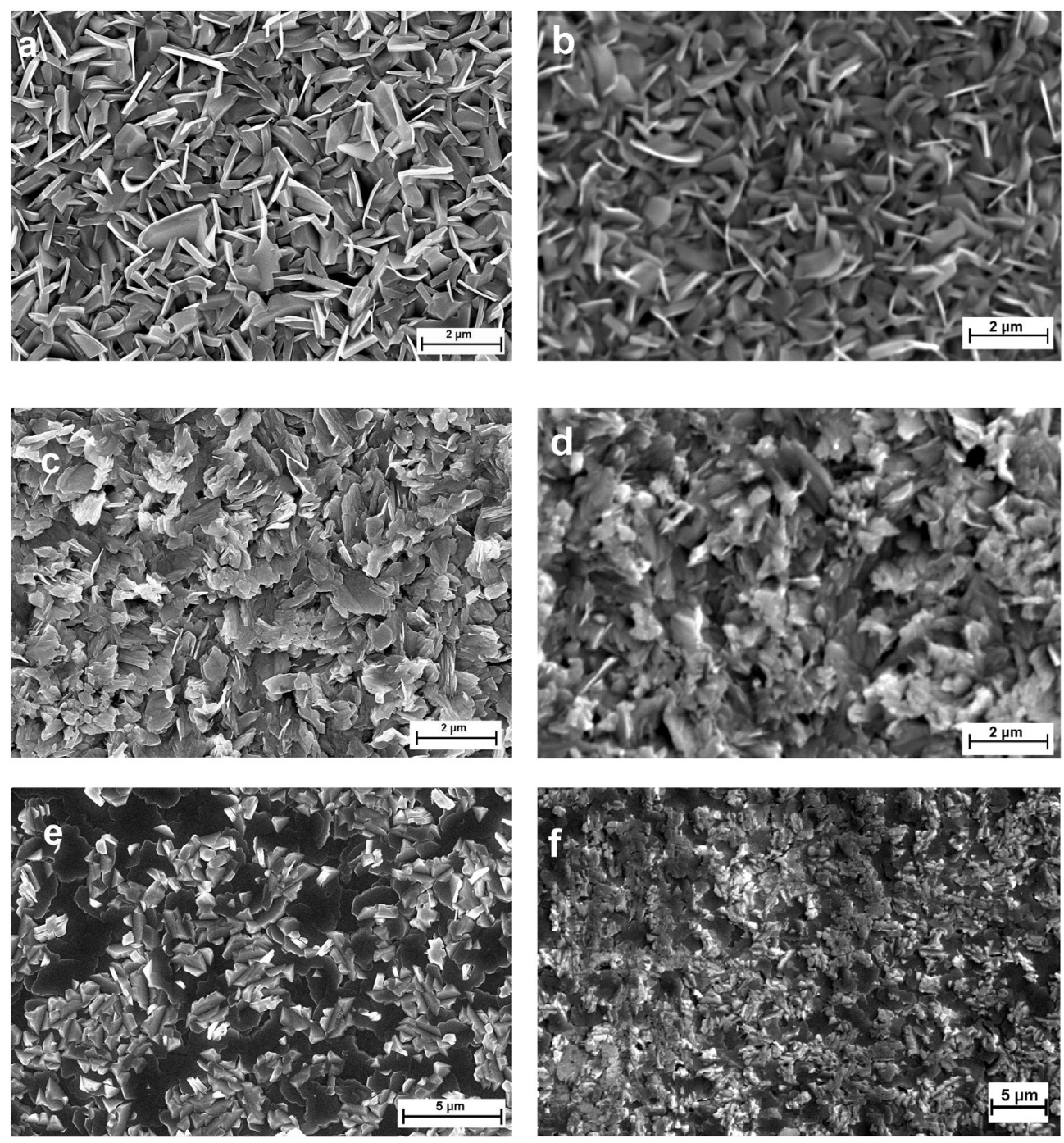

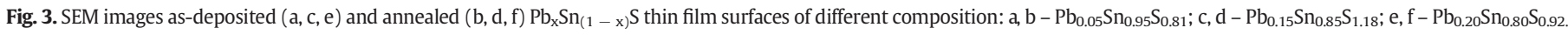

interesting inversion was previously observed by Devika et al. for SnS thin films obtained by thermal evaporation [12] and by us for metal rich $p$-type SnS thin films obtained by hot wall vacuum deposition [2, 5]. Generally, sulfur rich metal chalcogenide films are expected to be $p$-type and sulfur-deficient films are suggested to be $n$-type. The observed $p$-type of metal-rich $\mathrm{SnS}$ and $\mathrm{Pb}_{\mathrm{x}} \mathrm{Sn}_{(1-\mathrm{x})} \mathrm{S}$ films may be originated from inhomogeneity of the material, including sulfur-rich thin layer at the film surface reported in [5]. However, the complete explanation of the SnS and $\mathrm{Pb}_{\mathrm{x}} \mathrm{Sn}_{(1-\mathrm{x})} \mathrm{S}$ thin films conductivity type dependence on the preparation conditions requires further research.

Thermal probe measurements showed that the electrical resistance of the films does not depend on the lead concentration, stoichiometry and the conductivity type. However, the annealing causes resistance to decrease by almost an order of magnitude from 920 to $180 \Omega \cdot \mathrm{cm}$, while Seebeck coefficient increases from 15 to $150 \mu \mathrm{V} \cdot \mathrm{K}^{-1}$. Decrease of the resistivity accompanied by an increase of the Seebeck coefficient after heat treatment was previously observed for SnS films in [6]. In [4] for SnS-based solar cells we noted the high series resistance values of the elements due to high SnS resistance, which lowers the efficiency of photoelectrical conversion. The decrease of $\mathrm{Pb}_{\mathrm{x}} \mathrm{Sn}_{(1-\mathrm{x})} \mathrm{S}$ resistance after heat treatment, thus, indicates the feasibility of using this type of treatment for the preparation of $\mathrm{Pb}_{\mathrm{x}} \mathrm{Sn}_{(1-\mathrm{x})}$ S-based solar cells of increased efficiency.

The typical transmittance $(\mathrm{T})$ and reflectance $(\mathrm{R})$ spectra of the $\mathrm{Pb}_{\mathrm{x}} \mathrm{Sn}_{(1-\mathrm{x})} \mathrm{S}$ films are shown in Figs. 4 and 5. No change was observed in R spectra of the annealed films comparing to the as-deposited, and a very little change was found in T spectra for sulfur-deficient films. However, sulfur-rich films demonstrate significant decrease in $\mathrm{T}$ after the annealing. Relatively low $T$ and $R$ values $(T+R<70 \%$ at $\lambda=2500 \mathrm{~nm}$ ) indicate the presence of various losses in the region before the fundamental absorption edge, including light scattering and absorption driven by mechanisms non-connected with inter-band processes (lattice polarization, ionization of defect levels and bands etc.). The major reason of low $\mathrm{T}+\mathrm{R}$ in the mentioned region must be the light scattering due to the high surface roughness and pronounced polycrystalline nature of the films with crystallite size comparable to the light wavelength. Obviously, to effectively use the $\mathrm{Pb}_{\mathrm{x}} \mathrm{Sn}_{(1-\mathrm{x})} \mathrm{S}$ films in PVdevices, the scattering losses should be reduced.

The complete equations for $\mathrm{T}$ and $\mathrm{R}$ as functions of complex refraction indexes of a film and a substrate $n_{1}+i k_{1}$ and $n_{2}+i k_{2}$, respectively, film thickness $d$, non-absorbing media refraction index $n_{0}$ and incident light wavelength $\lambda$ were given by Heavens [19] and, in more compact form, by Tomlin [36]. For high-absorptive films this equations reduce to the following [36]:

$$
\mathrm{T}=\frac{16 n_{0} n_{s}\left(n_{1}^{2}+k_{1}^{2}\right)}{\left(\left(n_{1}+n_{2}\right)^{2}+\left(k_{1}+k_{2}\right)^{2}\right)\left(\left(n_{0}+n_{1}\right)^{2}+k_{1}^{2}\right)} \exp \left(-\frac{4 \pi k_{1} d}{\lambda}\right)
$$




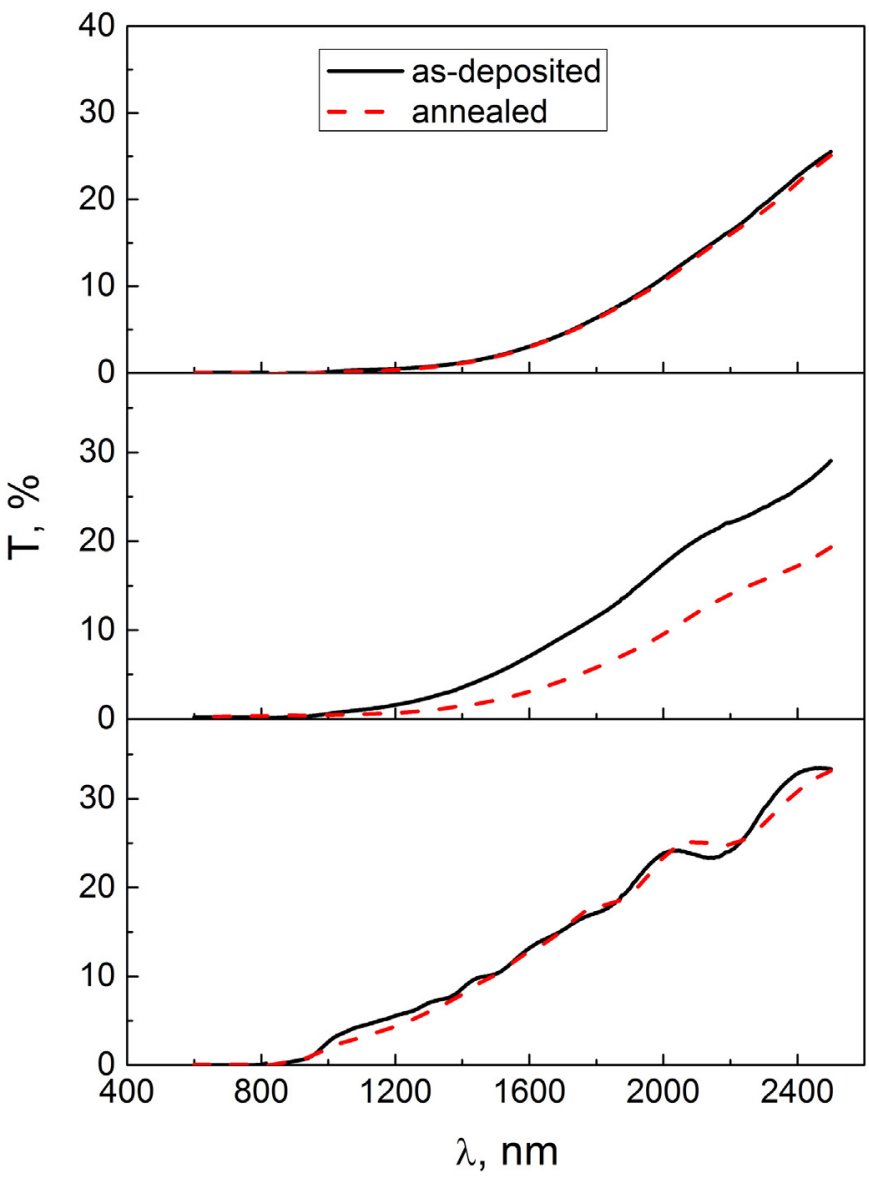

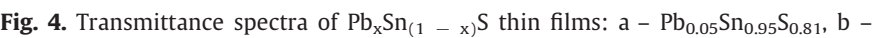
$\mathrm{Pb}_{0.15} \mathrm{Sn}_{0.85} \mathrm{~S}_{1.18}, \mathrm{c}-\mathrm{Pb}_{0.20} \mathrm{Sn}_{0.80} \mathrm{~S}_{0.92}$.

$\mathrm{R}=\frac{\left(n_{0}-n_{1}\right)^{2}+k_{1}^{2}}{\left(n_{0}+n_{1}\right)^{2}+k_{1}^{2}}$

$\alpha=\frac{4 \pi k_{1}}{\lambda}$

Taken $n_{0}=1$ for air, $k_{2}=0$ and $n_{2}=1.5+\left(4.5 \cdot 10^{3} \mathrm{~nm}^{2}\right) \lambda^{-2}$ for glass substrate, the system of Eqs. ( 7 ) and (8) can be solved numerically

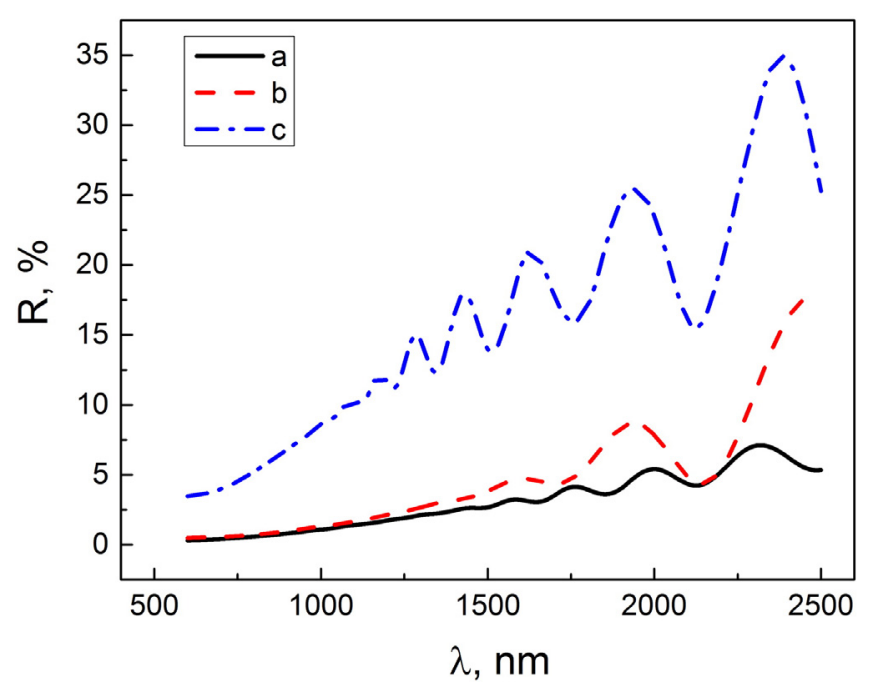

Fig. 5. Reflectance spectra of $\mathrm{Pb}_{\mathrm{x}} \mathrm{Sn}_{(1-\mathrm{x})} \mathrm{S}$ thin films: a $-\mathrm{Pb}_{0.05} \mathrm{Sn}_{0.95} \mathrm{~S}_{0.81}$, b $\mathrm{Pb}_{0.15} \mathrm{Sn}_{0.85} \mathrm{~S}_{1.18}, \mathrm{c}-\mathrm{Pb}_{0.20} \mathrm{Sn}_{0.80} \mathrm{~S}_{0.92}$. to achieve $n_{1}$ and $k_{1}$ for each $\lambda$ and then to calculate the absorption coefficient $\alpha$ by the Eq. (9).

Note, that since these relations do not contain trigonometrically terms responsible for interference, oscillations of calculated values may occur if the film thickness is comparable to $\lambda$. For the precise determination of the optical parameters the complete equations from [19] should be used. However, the Eqs. (7)-(9) may be considered as a good approximation allowing to obtain adequate $\alpha$ spectra near the fundamental absorption edge. Facing low reflectance, we obtained relatively low values of $n_{1} \sim 1.8-2.0$ for $\mathrm{Pb}_{\mathrm{x}} \mathrm{Sn}_{(1-\mathrm{x})} \mathrm{S}$ thin films with $0.05<x<0.15$ and $n_{1}$ up to 3.0 for $x=0.2$.

The calculated $\alpha$ spectra are presented in Fig. 6. Generally, the spectra demonstrate a continuous increase of $\alpha$ at the spectral range of 0.4$1.5 \mathrm{eV}$, maintaining a constant level of $3-4 \cdot 10^{4} \mathrm{~cm}^{-1}$ at the range of $1.5-2 \mathrm{eV}$. This may be explained by the large film thickness leading to $\mathrm{T}$ and $\mathrm{R}$ falling below the detection range.

Near the absorption edge $(\alpha h \nu)^{n} \sim\left(h \nu-E_{g}\right)$, where $n$ is $2,2 / 3,1 / 2$ or $1 / 3$ for direct allowed, direct prohibited, indirect allowed and indirect prohibited band transitions, respectively [28]. The absorption coefficient spectra in the $(\alpha h v)^{2}=f(h v)$ coordinates are presented in Fig. 7. According to the spectral analysis, the $\mathrm{Pb}_{\mathrm{x}} \mathrm{Sn}_{(1-\mathrm{x})} \mathrm{S}$ films exhibit direct allowed transitions with energy band gap $E_{g(d)}$ values of $0.95-$ $0.98 \mathrm{eV}$ for as-deposited films and $0.90-0.94 \mathrm{eV}$ - for annealed films, depending on the film composition. The $E_{g(d)}$ values demonstrate minor increase with the increase of $\mathrm{Pb}$ mole fraction. The tendency of $E_{g(d)}$ to increase with the increase of $\mathrm{Pb}$ mole fraction $x$ was previously observed in [22] for $x$ in the range from 0.25 to 0.45 . However, in the current work this tendency is much less than in [22]. The absorption spectra of the sulfur-deficient films' contain interesting peculiarities in spectral range of $1.2-1.5 \mathrm{eV}$, that may indicate the impurity or defect levels in

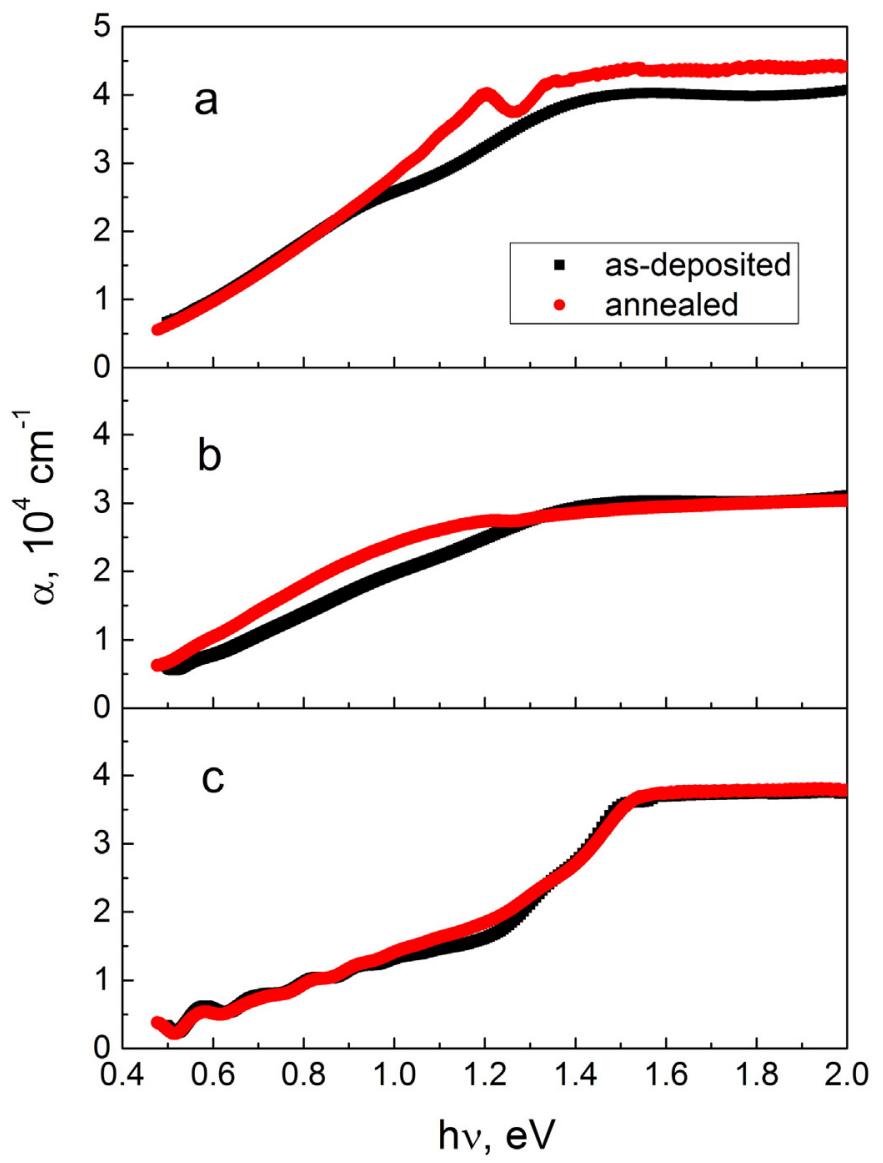

Fig. 6. Absorption coefficient spectra of $\mathrm{Pb}_{\mathrm{x}} \mathrm{Sn}_{(1-\mathrm{x})} \mathrm{S}$ films: $\mathrm{a}-\mathrm{Pb}_{0.05} \mathrm{Sn}_{0.95} \mathrm{~S}_{0.81}$, b $\mathrm{Pb}_{0.15} \mathrm{Sn}_{0.85} \mathrm{~S}_{1.18}, \mathrm{c}-\mathrm{Pb}_{0.20} \mathrm{Sn}_{0.80} \mathrm{~S}_{0.92}$. 


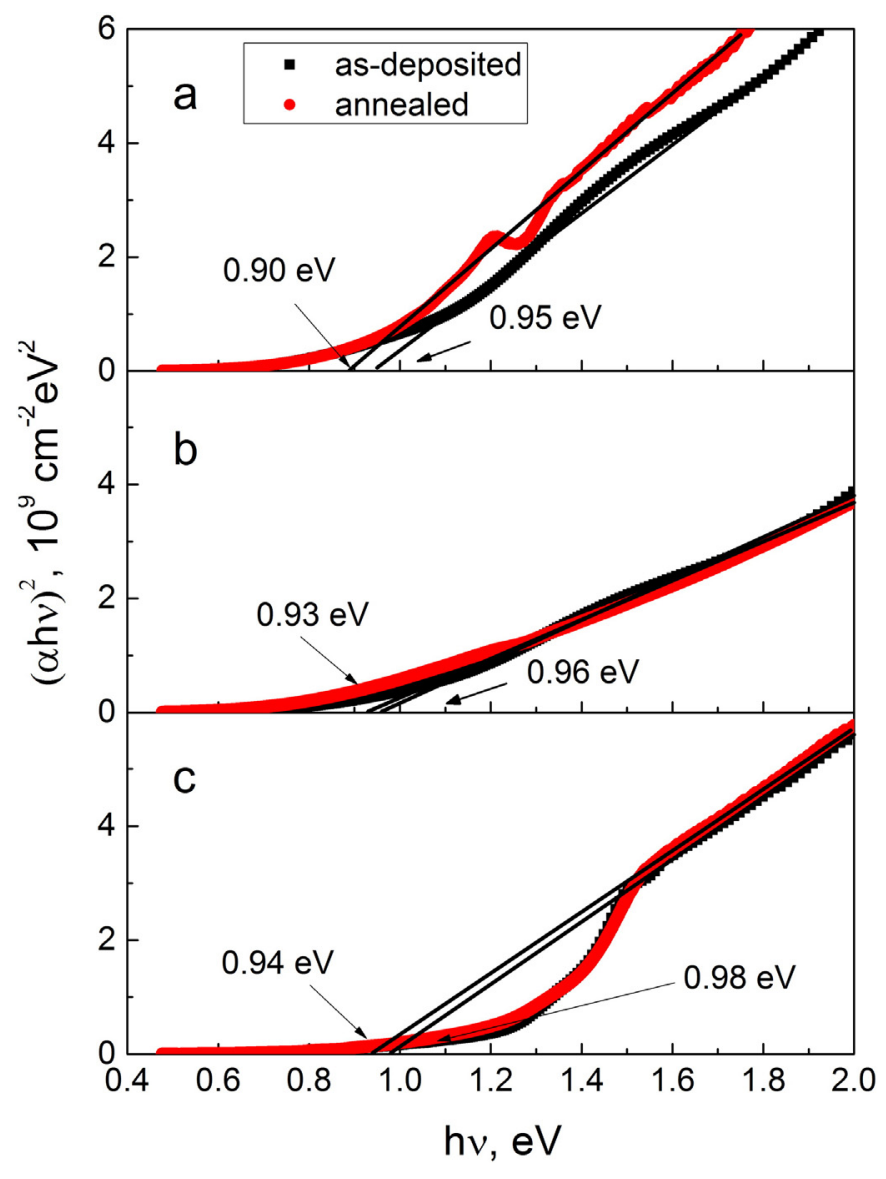

Fig. 7. $(\alpha h v)^{2}$ versus photon energy plots of $\mathrm{Pb}_{\mathrm{x}} \mathrm{Sn}_{(1-\mathrm{x})} \mathrm{S}$ films: $\mathrm{a}-\mathrm{Pb}_{0.05} \mathrm{Sn}_{0.95} \mathrm{~S}_{0.81}, \mathrm{~b}-$ $\mathrm{Pb}_{0.15} \mathrm{Sn}_{0.85} \mathrm{~S}_{1.18}, \mathrm{c}-\mathrm{Pb}_{0.20} \mathrm{Sn}_{0.80} \mathrm{~S}_{0.92}$.

the band structure of the material. The step-form absorption in the mentioned spectral range was previously observed for SnS thin films [6]. Thus, the optical behavior of $\mathrm{SnS}$ and $\mathrm{Pb}_{\mathrm{x}} \mathrm{Sn}_{(1-\mathrm{x})} \mathrm{S}$ thin films near the fundamental absorption edge requires further deep examination.

\section{Conclusions}

The influence of the annealing in vacuum on the microstructure and optical properties of $\mathrm{Pb}_{\mathrm{x}} \mathrm{Sn}_{(1-\mathrm{x})} \mathrm{S}$ films obtained by HWVD method is reported. It was shown that in the $\mathrm{Pb}$ mole fraction $x$ range from 0.05 to 0.20 the films consist of the orthorhombic $\mathrm{Pb}_{\mathrm{x}} \mathrm{Sn}_{(1-\mathrm{x})} \mathrm{S}$ phase with $\alpha$-SnS structure. The lattice parameter deviations from the bulk crystals for both as-deposited and annealed $\mathrm{Pb}_{\mathrm{x}} \mathrm{Sn}_{(1-\mathrm{x})} \mathrm{S}$ thin films were observed and the possible explanation was discussed.

According to XRD data, the annealing leads to microstrain $\varepsilon$ decrease and to grain size $D$ increase that may be caused by the surface energy reduction due to minimization of the specific surface area. $\mathrm{Pb}_{\mathrm{x}} \mathrm{Sn}_{(1-\mathrm{x})} \mathrm{S}$ thin films in the whole examined composition range exhibited a preferred orientation in the [111] direction with a typical degree of $41 \%$, increasing after the annealing by $1-2 \%$.

Thermal probe measurements showed that the sulfur deficient films are $p$-type and the sulfur rich films are $n$-type. The film electrical resistance of the films does not depend on the lead concentration, stoichiometry and the conductivity type. The annealing causes the resistance to decrease from 920 to $180 \Omega \cdot \mathrm{cm}$, while Seebeck coefficient increases from 15 to $150 \mu \mathrm{V} \cdot \mathrm{K}^{-1}$.

$\mathrm{The} \mathrm{Pb}_{\mathrm{x}} \mathrm{Sn}_{(1-\mathrm{x})} \mathrm{S}$ films exhibit direct allowed transitions with energy band gap $E_{g(d)}$ values from 0.95 to $0.98 \mathrm{eV}$ for as-deposited films and from 0.90 to $0.94 \mathrm{eV}$ for annealed films increasing with the increase of $\mathrm{Pb}$ mole fraction.

\section{Acknowledgments}

This work has been supported by Belarusian Republican Foundation for Fundamental Research (project F14M-001) and Russian Foundation for Basic Research (project Op 15-32-50261\15).

\section{References}

[1] U.V. Alpen, J. Fenner, E. Gmelin, Semiconductors of the type $\mathrm{Me}^{\mathrm{II}} \mathrm{Me}^{\mathrm{IV}} \mathrm{S}_{3}$, Mater. Res. Bull. 10 (1975) 175-180.

[2] S.A. Bashkirov, V.F. Gremenok, V.A. Ivanov, Physical properties of SnS thin films fabricated by hot wall deposition, Semiconductors 45 (2011) 749-752.

[3] S.A. Bashkirov, V.V. Lazenka, V.F. Gremenok, K. Bente, Microstructure of SnS thin films obtained by hot wall vacuum deposition method, J. Adv. Microsc. Res. 6 (2011) 153-158.

[4] S.A. Bashkirov, V.F. Gremenok, V.A. Ivanov, V.V. Lazenka, K. Bente, Tin sulfide thin films and Mo/p-SnS/n-CdS/ZnO heterojunctions for photovoltaic application, Thin Solid Films 520 (2012) 5807-5810.

[5] S.A. Bashkirov, V.F. Gremenok, V.A. Ivanov, V.V. Shevtsova, Microstructure and electrical properties of SnS thin films, Phys. Solid State 54 (2012) 2497-2502.

[6] S.A. Bashkirov, P.P. Gladyshev, V.F. Gremenok, V.A. Ivanov, Influence of thermal treatment on the microstructure and electrical and optical properties of SnS thin films, Phys. Solid State 56 (2014) 1310-1314.

[7] M. Calixto-Rodriguez, H. Martinez, A. Sanchez-Juarez, J. Campos-Alvarez, A. Tiburcio-Silver, M.E. Calixto, Structural, optical, and electrical properties of tin sulfide thin films grown by spray pyrolysis, Thin Solid Films 517 (2009) 2497-2499.

[8] C. Cifuentes, M. Botero, E. Romero, C. Calderon, G. Gordillo, Optical and structural studies on SnS films grown by co-evaporation, Braz. J. Phys. 36 (2006) 1046-1049.

[9] R. Delhez, T.R. de Keijser, E.J. Mittemeijer, J.I. Langford, Size and strain parameters from peak profiles: sense and nonsense, Aust. J. Phys. 41 (1988) 213-228.

[10] M. Devika, N. Koteeswara Reddy, K. Ramesh, V. Ganesan, E.S.R. Gopal, K.T. Ramakrishna Reddy, Influence of substrate temperature on surface structure and electrical resistivity of the evaporated tin sulphide films, Appl. Surf. Sci. 253 (2006) 1673-1676.

[11] M. Devika, N.K. Reddy, K. Ramesh, K.R. Gunasekhar, E.S.R. Gopal, K.T.R. Reddy, Influence of annealing on physical properties of evaporated SnS films, Semicond. Sci. Technol. 21 (2006) 1125-1131.

[12] M. Devika, N.K. Reddy, D.S. Reddy, S.V. Reddy, K. Ramesh, E.S.R. Gopal, K.R Gunasekhar, V. Ganesan, Y.B. Hahn, Optimization of the distance between source and substrate for device-grade SnS films grown by the thermal evaporation technique, J. Phys. Condens. Matter 19 (2007) 306003 (12pp).

[13] W.A. Dollase, Correction of intensities for preferred orientation in powder diffractometry: application of the March model, J. Appl. Crystallogr. 19 (1986) 267-272.

[14] A.R.H.F. Ettema, R.A. de Groot, C. Haas, Electronic structure of SnS deduced from photoelectron spectra and band-structure calculations, Phys. Rev. B 46 (1992) 7363-7373.

[15] V.F. Gremenok, V.Y. Rud, Y.V. Rud, S.A. Bashkirov, V.A. Ivanov, Photosensitive thinfilm $\mathrm{In} / \mathrm{p}-\mathrm{Pb}_{\mathrm{x}} \mathrm{Sn}_{1}-{ }_{\mathrm{x}} \mathrm{S}$ Schottky barriers: fabrication and properties, Semiconductors 45 (2011) 1053-1058.

[16] E. Guneri, F. Gode, C. Ulutas, F. Kirmizigul, G. Altindemir, C. Gumus, Properties of ptype $\mathrm{SnS}$ thin films prepared by chemical bath deposition, Chalcogenide Lett. 7 (2010) 685.

[17] K. Hartman, J.L. Johnson, M.I. Bertoni, D. Recht, M.J. Aziz, M.A. Scarpulla, T. Buonassisi, SnS thin-films by RF sputtering at room temperature, Thin Solid Films 519 (2011) 7421-7424.

[18] K. Hayashi, A. Kitakaze, A. Sugaki, A re-examination of herzenbergite-teallite solid solution at temperatures between 300 and $700{ }^{\circ} \mathrm{C}$, Mineral. Mag. 65 (2001) 645-651.

[19] O.S. Heavens, Optical Properties of Thin Solid Films, Butterworth, London, 1955.

[20] V.V. Lazenka, K. Bente, R. Kaden, V.A. Ivanov, V.F. Gremenok, Microstructure and composition of $\mathrm{Sn}_{1}-{ }_{x} \mathrm{~Pb}_{\mathrm{x}} \mathrm{S}$ films and whiskers grown by hot wall technique, J. Adv. Microsc. Res. 6 (2011) 153-158.

[21] V. Leute, A. Behr, C. Hünting, H.M. Schmidtke, Phase diagram and diffusion properties of the quasibinary system (Sn, Pb)S, Solid State Ionics 68 (1994) 287-294.

[22] S. Lobe, G. Wagner, K. Bente, From SnS and PbS towards complex sulfosalts: thin film growth and properties, Phys. Status Solidi C 10 (2013) 1139-1144.

[23] A. Lopez-Otero, Hot wall epitaxy, Thin Solid Films 49 (1978) 3-57.

[24] L. Lutterotti, S. Matthies, H.R. Wenk, MAUD (Material Analysis Using Diffraction): A User Friendly Java Program for Rietveld Texture Analysis and More, Proceeding of the Twelfth International Conference on Textures of Materials (ICOTOM-12) 1, 19991599.

[25] L. Makinistian, E.A. Albanesi, On the band gap location and core spectra of orthorhombic IV-VI compounds SnS and SnSe, Phys. Status Solidi B 246 (2009) 183-191.

[26] J. Malaquias, P.A. Fernandes, P.M.P. Salomé, A.F. da Cunha, Assessment of the potential of tin sulphide thin films prepared by sulphurization of metallic precursors as cell absorbers, Thin Solid Films 519 (2011) 7416-7420.

[27] A. March, Mathematische theorie der regelung nach der korngestat bei affner deformation, Z. Kristallogr. 81 (1932) 285-297.

[28] J.I. Pankove, Optical Processes in Semiconductors, Dover, New York, 1971. 
[29] H.M. Rietveld, A profile refinement method for nuclear and magnetic structures, J. Appl. Crystallogr. 2 (1969) 65-71.

[30] P. Sinsermsuksakul, J. Heo, W. Noh, A.S. Hock, R.G. Gordon, Atomic layer deposition of tin monosulfide thin films, Adv. Energy Mater. 1 (2011) 1116-1125.

[31] P. Sinsermsuksakul, K. Hartman, S.B. Kim, J. Heo, L. Sun, H.H. Park, R. Chakraborty, T. Buonassisi, R.G. Gordon, Enhancing the efficiency of SnS solar cells via band-offset engineering with a zinc oxysulfide buffer layer, Appl. Phys. Lett. 102 (2013) 053901.

[32] P. Sinsermsuksakul, L. Sun, S.W. Lee, H.H. Park, S.B. Kim, C. Yang, R.G. Gordon, Overcoming efficiency limitations of SnS-based solar cells, Adv. Energy Mater. 4 (2014) 1400496.

[33] I.V. Slipukhina, D.M. Bercha, Elementary energy bands in isovalent IV-VI orthorhombic and cubic crystals and their solid solutions, Phys. Status Solidi B 244 (2007) 650-668.

[34] R.B. Soriano, C.D. Malliakas, J. Wu, M.G. Kanatzidis, Cubic form of $\mathrm{Pb}_{2}-{ }_{x} \mathrm{Sn}_{\mathrm{x}} \mathrm{S}_{2}$ stabilized through size reduction to the nanoscale, J. Am. Chem. Soc. 134 (2012) 3228-3233.

[35] A. Tanuševski, D. Poelman, Optical and photoconductive properties of SnS thin films prepared by electron beam evaporation, Sol. Energy Mater. Sol. Cells 80 (2003) 297-303.
[36] S.G. Tomlin, Optical reflection and transmission formulae for thin films, J. Phys. D. Appl. Phys. 1 (1968) 1667-1671.

[37] D.M. Unuchak, K. Bente, G. Kloess, W. Schmitz, V.F. Gremenok, V.A. Ivanov, V. Ukhov, Structure and optical properties of PbS-SnS mixed crystal thin films, Phys. Status Solidi C 6 (2009) 1191-1194.

[38] A.A. Volykhov, V.I. Shtanov, L.V. Yashina, Phase relations between germanium, tin, and lead chalcogenides in pseudobinary systems containing orthorhombic phases, Inorg. Mater. 44 (2008) 345-356.

[39] G. Wagner, R. Kaden, V. Lazenka, K. Bente, Microstructure of $\mathrm{Sn}_{1}{ }_{x} \mathrm{~Pb}_{\mathrm{x}} \mathrm{S}$ grown by hot-wall technique, Phys. Status Solidi A. 208 (2011) 2150-2158.

[40] W.A. West, A.W.C. Menzies, The vapor pressures of sulphur between $100^{\circ}$ and $550^{\circ}$ with related thermal data, J. Phys. Chem. 33 (1929) 1880-1892.

[41] S.P. Zimin, E.S. Gorlachev, I.I. Amirov, V.V. Naumov, G.A. Dubov, V.F. Gremenok, S.A. Bashkirov, Investigations of nanocrystalline SnS films' surface morphology modification during inductively coupled argon plasma sputtering, Semicond. Sci. Technol. 29 (2014) 015009

[42] E. Zolotoyabko, Determination of the degree of preferred orientation within the March-Dollase approach, J. Appl. Crystallogr. 42 (2009) 513-518. 